\title{
FUNGSI KOGNITIF DAN PRAGMATIK METAFORA DALAM DEBAT PILGUB DKI JAKARTA 2017
}

The Cognitive and Pragmatic Functions of Metaphors in the Debate of 2017 Jakarta Governor Election

\author{
Aliurridha dan Anwar Efendi \\ Universitas Negeri Yogyakarta \\ ridhokdi@gmail.comdan efendianwar@ymail.com
}

Naskah Diterima Tanggal 7 Maret 2019-Direvisi Akhir Tanggal 5 Januari 2021—Disetujui Tanggal 31 Mei 2021 doi: https://doi.org/10.26499/rnh.v10i1.1328

\begin{abstract}
Abstrak
Metafora telah lama menjadi kajian sastra, tetapi pengkajian metafora pada wacana politik di Indonesia masih sangat jarang. Penelitian tentang metafora kebanyakan masih terbatas pada menemukan jenis dari metafora, tetapi kajian mengenai fungsi metafora masih jarang dilakukan. Selain itu, penelitian metafora masih didominasi oleh pendekatan semantik daripada pendekatan pragmatik. Padahal, metafora merupakan bagian dari penggunaan bahasa. Penelitian ini bertujuan untuk menemukan fungsi kognitif dan pragmatik metafora pada debat pemilihan Gubernur Jakarta. Metode yang digunakan adalah metode kualitatif dengan pendekatan kognitif dan pragmatik. Data dikumpulkan dengan metode simak dengan teknik baca tulis. Data dianalisis dengan metode padan referensial dan inferensi abduktif. Hasil penelitian menunjukkan bahwa sebagian besar ungkapan metaforis yang ditemukan dalam penelitian ini secara kognitif memiliki fungsi ontologikal dan fungsi struktural. Sementara itu, secara pragmatik metafora berfungsi untuk memengaruhi pendengar dengan menggunakan ranah sasaran yang dekat dengan kehidupan sehari-hari. Secara umum metafora yang muncul pada debat pemilihan Gubernur DKI Jakarta memiliki fungsi untuk membantu menyederhanakan isu-isu politik yang abstrak dan rumit.
\end{abstract}

Kata-kata kunci: metafora, kognitif linguistik, pragmatik, wacana politik

\section{Abstract}

Metaphors have long been studied in literature yet the study of metaphors on the political discourse of Indonesia is still difficult to be found. The researches on metaphors are mostly in finding the type of metaphor but rarely studies the function of metaphor. In addition, the researches on metaphors are still dominated by a semantic approach rather than a pragmatic approach, whereas metaphor is part of the language in use. This study aims to find the cognitive and pragmatic functions of metaphors in the debate of the 2017 Jakarta Governor election. The method in this research was a qualitative method with cognitive and pragmatic approaches. The data were collected by the read and record techniques. The data were analyzed by the referential and abductive inference method. The result of this study shows that most metaphorical expressions found in this study cognitively have ontological and structural functions. Whereas, pragmatically metaphors have a function to influence listeners by using target domains that are close to everyday life. In general, the metaphors that emerged at the debate of the 2017 DKI Jakarta Governor election have a function to help simplify abstract and complex political issues.

Keywords: metaphor, linguistic cognitive, pragmatic, political discourse

How to Cite: Aliurridha dan Anwar Efendi. (2021). Fungsi Kognitif dan Pragmatik Metafora dalam Debat Pilgub Dki Jakarta 2017. Ranah: Jurnal Kajian Bahasa. 10(1). 132-143. doi: https://doi.org/10.26499/rnh.v10i1.1328 


\section{PENDAHULUAN}

Metafora telah lama menjadi kajian dalam bidang sastra. Selama bertahun-tahun metafora hanya dilihat sebagai kiasan yang terbatas penggunaanya pada puisi, prosa, atau retorikasebelum dianggap sebagai fenomena kognitif. Namun, ide revolusioner dari George Lakoff dan Mark Johnson (1980) telah mengubah perspektif metafora yang, tidak hanya dilihat sebagai permasalahan dalam bahasa dan sastra tetapi juga sebagai konsep yang mengatur cara berpikir manusia. Namun, masih ada ahli bahasa yang kebingungan dalam membedakan antara metafora sebagai konsep dan metafora sebagai produk, yakni berupa ekspresi linguistik. Sebagai contoh, Sukarno (2017) gagal dalam memahami perbedaan antara metafora sebagai sistem konseptual (metafora konseptual) dan metafora sebagai ekspresi linguistik. Ia membuat contoh ekspresi linguistik dari metafora "argumen adalah perang" yang diambil dari Lakoff metafora konseptual dan Johnson (1980: 4) Argument is War (Sukarno, 2017: 17). Sukarno menerjemahkan metafora konseptual ini dan menggunakannya sebagai contoh di mana ia gagal memahami bahwa metafora itu sebenarnya merupakan konsep yang mengatur sistem kognisi manusia bukanlah sebagai ekspresi linguistik. Lakoff dan Johnson (1980) selalu menggunakan contoh metafora dalam sistem konseptual dan menggunakan huruf kapital untuk membuat perbedaan dengan metafora sebagai ekspresi linguistik yang digunakan dengan huruf miring.

Meskipun metafora kini mulai dianggap sebagai fenomena kognitif, tetapi sebagian besar ahli mempelajari metafora melalui bahasa, yakni lewat ekspresi linguistik dari ungkapan metaforis. Namun, dalam bahasa Indonesia studi metafora sebagian besar masih didominasi pada kajian sastra seperti puisi (Supriyadi, 2013; Ulya, Eko, \& Mujiyanto, 2016), surat kabar (Nirmala, 2011, 2012; Sukarno, 2017), ceramah (Hartanto, 2018), lagu (Ranabumi, 2018) dan masih susah sekali ditemukan kajian metafora dalam wacana politik. Selain itu, sedikit sekali kajian metafora dengan pendekatan kognitif. Supriyadi (2013) berfokus pada simbol-simbol dalam ruang persepsi manusia yang membentuk makna metaforis, sedangkan Ulya, Eko, W., dan Mujiyanto ( 2016) dan Ranabumi ( 2018) hanya mengkaji jenis-jenis metafora. Nirmala ( 2011, 2012), Sukarno (2017), dan Hartanto (2018) telah menggunakan pendekatan kognitif, tetapi hanya untuk menemukan transfer makna antara ranah sumber ke ranah sasaran tanpa usaha untuk memahami fungsi kognitif dari tuturan metaforis.

Lakoff dan Johnson (1980: 1) menjelaskan bahwa metafora memainkan peran sentral dalam mendefinisikan realitas sehari-hari. Ini berarti metafora digunakan dalam berbagai bidang kehidupan manusia. Salah satu ranah yang mengandung banyak ekspresi metaforis adalah ranah wacana politik. Politik dan metafora adalah dua hal yang tidak dapat dipisahkan. Politisi menggunakan metafora untuk menyatakan dan mengekspresikan ide-ide mereka karena ungkapan metaforis memiliki kekuatan persuasif sebagai alat retoris bagi politisi ketika berbicara kepada publik (Charteris-Black, 2011: 29-30). Lebih lanjut, Charteris-Black, (2011) menjelaskan bahwa metafora dapat digunakan untuk meningkatkan efek emosi dari penutur dengan membuatnya terdengar benar (hal, 313). Selain itu, Charteris-Black (2011) menjelaskan bahwa isu politik itu begitu rumit dan kompleks sehingga politisi yang baik harus mampu mengabstraksi isu politik dengan menggunakan ungkapan metaforis untuk membuat lebih dekat dan gampang dimengerti oleh berbagai kalangan masyarakat (hal. 31-32).

Dalam wacana politik, metafora memiliki fungsi dan karakteristik yang berbeda dengan metafora yang muncul pada ranah lain, seperti misalnya dalam karya sastra. Dalam karya sastra, metafora biasanya memiliki fungsi estetis (Supriyadi, 2013). Selain itu, dalam karya sastra metafora mudah diidentifikasi karena struktur metafora yang biasanya diformulasikan dengan $A$ adalah B. Seperti dalam karya fiksi Shakespeare yang terkenal, Romeo dan Juliet, di mana muncul metafora terkenal "Juliet is sun". Selain itu, metafora dalam sastra adalah ungkapan linguistik yang inovatif yang membuatnya mudah dikenali karena sifat metaforisitas mereka. Sebaliknya, metafora konvensional yang telah memasuki leksikon percakapan sehari-hari 
biasanya susah dikenali, misalnya, ungkapan "kita berada di jalan yang berbeda" yang digunakan ketika seseorang ingin mengakhiri sebuah hubungan.

Setiap budaya memiliki metaforanya sendiri dan setiap orang juga memiliki metaforanya sendiri-karena metafora secara kognitif merefleksikan apa yang dialami, dirasakan, dalam kehidupan sehari-hari (Lakoff \& Johnson, 1980: 3). Pemelajaran ungkapan metaforis dalam wacana politik diharapkan dapat memberikan gambaran mengenai pola pikir seseorang, bagaimana dia mengkonstruksi ide, hingga sikapnya terhadap isu tertentu. Selanjutnya, penelitian ini juga diharapkan dapat menambah dan memperluas khazanah pengkajian metafora. Oleh karena itu, penting sekali untuk mengkaji fungsi kognitif dan pragmatik ungkapan metafora yang digunakan pada debat pemilihan Gubernur DKI Jakarta tahun 2017 yang begitu diwarnai dengan pertarungan wacana yang memunculkan berbagai ungkapan metaforis.

Berdasarkan latar belakang yang telah dijelaskan terdapat beberapa masalah yang ditemukan. Pertama, susahnya menemukan kajian metafora dalam wacana politik karena dalam Bahasa Indonesia metafora masih terbatas pada ranah karya sastra dan seni, jarang sekali pada ranah politik. Kedua, penelitan yang membahas metafora masih jarang yang menggunakan pendekatan kognitif, hanya terbatas pada pendekatan kebahasaan-jika pun ada yang menggunakan pendekatan kebahasaan masih sebatas untuk menemukan ranah sumber dan ranah sasaran dalam tuturan metaforis, belum ada yang sampai menemukan fungsi kognitif dari metafora. Ketiga, metafora juga berhubungan dengan penggunaan bahasa atau muncul dalam tataran wacana maka peting untuk mengkaji fungsi pragmatis dari tuturan metaforis. Dari penjelasan itu, maka terdapat dua masalah yang ingin dijawab dalam penelitian ini, yakni 1) fungsi kognitif apa saja yang muncul dari ungkapan metaforis dalam debat pemilihan Gubernur DKI Jakarta tahun 2017 dan 2) fungsi pragmatik apa saja yang muncul dari ungkapan metaforis dalam debat pemilihan Gubernur DKI Jakarta tahun 2017

\section{LANDASAN TEORI}

Inti dari metafora adalah untuk memahami sesuatu dengan istilah yang berbeda (Lakoff \& Johnson, 1980: 1). Metafora sebagai proses adalah konsep yang terjadi dalam sistem kognisi manusia yang produknya paling sering berupa ungkapan linguistik. Lakoff dan Johnson (1980: 1) selanjutnya mendefinisikan metafora sebagai proses kognitif yang memungkinkan manusia untuk memahami suatu ranah pengalaman-yang didefinisikan sebagai ranah sumber, untuk mendefinisikan istilah dari ranah lainnya-yakni ranah sasaran. Ranah sasaran ini biasanya merupakan konsep yang abstrak atau fenomena baru yang didefinisikan dengan istilah dari sesuatu yang lebih konkret atau pengalaman yang lebih spesifik dan akrab. Newmark (1988: 104) mendefinisikan metafora sebagai ekspresi figuratif yang mentransfer sifat dari kata yang konkret ke kata yang lebih abstrak. Dia mendefinisikan metafora sebagai personifikasi dari sebuah abstraksi. Metafora dapat berupa kata atau kolokasi apa pun yang secara figuratif memiliki fungsi untuk menggambarkan satu hal dengan menggunakan istilah yang lain.

Metafora pada umumnya dikenal sebagai perangkat sastra yang memungkinkan manusia untuk membuat perbandingan antara dua objek, dua ide, atau dua situasi yang berbeda. Lebih dari itu, masih banyak yang mengira metafora hanya muncul pada karya sastra seperti puisi, novel-novel fiksi, maupun nonfiksi. Namun, metafora ternyata banyak digunakan sebagai alat komunikasi sehari-hari karena metafora adalah sistem konseptual yang membantu kita mendefinisikan realitas (Lakoff \& Johnson, 1980: 1). Disadari atau tidak, kita menggunakannya dalam kehidupan sehari-hari (Goatly, 1997: 3). Ketika seorang penutur mencoba menggambarkan sesuatu tentang perasaan mereka atau pengalaman mereka, semuanya dimulai dengan proses kognitif dalam otaknya. Penutur mulai membentuk proposisi ringkas dan relevan untuk menyampaikan ide-idenya. Untuk berkomunikasi, mereka akan membuat semacam sandi 
dengan menggunakan kode linguistik yang sesuai dengan makna gagasan yang ada dalam bentuk fisik. Pendengar mengartikan maknanya dengan menebak apa yang dipikirkan oleh pembicara. Misalnya ketika seseorang mengatakan "argumennya lemah dan dia tidak mampu mempertahankannya", atau "dia menghancurkan semua argumen saya" atau "dia menyerang setiap titik lemah dalam argumen saya", atau "saya tidak pernah menang berdebat dengannya," di sini dapat dipahami bahwa adanya metafora konseptual BERDEBAT ADALAH PERANG yang memunculkan berbagai ungkapan metaforis. Konsep abstrak seperti debat didefinisikan menggunakan berbagai leksikon perang.

Dari penjelasan di atas dapat dibedakan antara mana metafora yang berupa metafora konseptual dan mana yang berupa ungkapan metaforis. Metafora konseptual merupakan proses kognitif yang melandasi munculnya ungkapan metaforis. Metafora konseptual atau juga dikenal dengan metafora kognitif memiliki tiga fungsi, yakni fungsi struktural, fungsi orientasional, dan fungsi ontologis (Kövecses, 2010: 37). Ketiga fungsi ini diambil berdasarkan tipologi metafora konseptual Lakoff dan Johnson (1980). Fungsi struktural membantu manusia dalam memahami konsep abstrak atau fenomena baru atau pengalaman rumit yang abstrak dengan konseptualisasi dari sesuatu yang lebih konkret seperti pengalaman sederhana, khusus, dan akrab. Sebagai contoh ketika fenomena kemunculan atau dikenalnya virus, manusia mulai mengonseptualisasikan virus sebagai musuh dengan menggunakan metafora perang. Jadi mucul-lah metafora konseptual VIRUS ADALAH MUSUH yang melahirkan ungkapan metaforis seperti "virus mulai menginvansi tubuh anak itu", "tubuhnya melawan virus itu", dan "anak itu kembali sehat setelah sistem kekebalan memenangkan pertarungan". Sementara itu, fungsi orientasional membantu manusia mengatur konsep dari seluruh sistem berdasarkan orientasi spasial: naik-turun, masuk-keluar, maju-mundur, depan-belakang, dalam-dangkal, dan pusat-periferal. Misalnya dalam budaya penutur Bahasa Inggris ada orientasional metafora HAPPY IS UP dan SAD IS DOWN yang melahirkan ungkapan metaforis, "I'm feeling up," atau "my feeling is rose after finished the exam" yang menggambarkan kebahagiaan dengan gerakan spasial "naik" dan "Rina fell into depression" atau "my spirit sank" yang menggambarkan kesedihan dengan gerakan spasial "turun". Sementara itu, fungsi yang terakhir adalah fungsi ontologikal yang menyediakan pengalaman manusia dengan objek fisik untuk menghasilkan berbagai macam metafora konseptual (Lakoff \& Johnson, 1980: 25-26). Fungsi ini memiliki jangkauan dan tujuan yang sangat terbatas seperti merujuk (Kecintaan Anton pada judi membuat orang tuanya gila), menghitung (Banyak belajar dibutuhkan untuk lulus perguruan tinggi), mengidentifikasi (kengerian perang menggetarkan kita semua, tekanan dari pekerjaannya membuatnya gila). Lakoff dan Johnson (1980: 33) menjelaskan fungsi ontologis paling jelas dari metafora adalah mempersonifikasikan benda mati seolah-olah hidup.

Sebagai bagian dari penggunaan bahasa, metafora tidak cukup hanya dikaji dengan pendekatan semantik, karena pengkajian metafora akan berhenti pada makna tidak pada apa yang ada di balik makna. Maka dari itu, pengkajian metafora harus melihat konteks untuk memahami fungsi pragmatik metafora. Fungsi pragmatik pun sangat bervariasi tergantung pada konteks apa metafora ini digunakan. Pada wacana surat pembaca yang diteliti oleh Nirmala (2012) menemukan bahwa ungkapan metaforis yang mengindikasikan ketidaklangsungan maksud. Ketidaklangsungan maksud ini menunjukkan strategi kesopanan penulis surat pembaca untuk menjaga hubungan baik dengan pembaca. Selanjutnya, Sukarno (2017) yang meneliti fungsi pragmatik ungkapan metaforis pada surat kabar Jawa Pos menemukan metafora pada surat kabar Jawa Pos memiliki fungsi pragmatis untuk menyoroti, memopulerkan, dan mendramatisasi laporan berita dengan tujuan menarik perhatian pembaca. Metafora pada surat kabar Jawa Pos digunakan untuk mengkritik, mengintimidasi, dan merendahkan pengadilan, terutama jaksa dan hakim karena dianggap tidak netral dalam memutuskan. 
Untuk menemukan fungsi pragmatik metafora, konteks merupakan hal yang penting. Dalam penelitian ini konteks yang dianalisis meliputi konteks linguistik, konteks sosial, dan pengetahuan yang berupa pengalaman dari penutur (Croft \& Cruse, 2004: 102-103). Konteks linguistik meliputi wacana yang muncul sebelum tuturan metafora, lingkungan linguistik langsung yang merupakan frasa atau kalimat yang mengikuti tuturan metafora, dan jenis wacana yang meliputi genre, register, dan bidang wacana. Dalam politik di mana masyarakat demokratis yang pemimpinnya dipilih melalui pemilihan umum, politisi mengandalkan kemampuan mereka dalam berbahasa sebagai keterampilan retoris untuk memesona para pengikut mereka yang salah satunya menggunakan metafora (CharterisBlack, 2004, 2011). Metafora dalam wacana politik dapat digunakan untuk memengaruhi pendengar, untuk membujuk orang agar percaya pada apa yang dikatakan penutur (Charteris-Black, 2004, 2011; Goatly, 2007), dan untuk melegitimasi penutur dan mendelegitimasi lawan politiknya (CharterisBlack, 2011; Hellín-García, 2013: 304). Legitimasi adalah strategi yang digunakan politisi untuk menunjukkan bahwa mereka lebih dapat diandalkan daripada lawan mereka, sedangkan delegitimasi adalah strategi politisi menunjukkan kelemahan lawan atau kekurangan dari lawan politiknya.

\section{METODE PENELITIAN}

Penelitian ini termasuk penelitian kualitatif dengan pendekatan kognitif dan pragmatik. Pendekatan ini adalah pendekatan yang sesuai untuk mempelajari metafora sebagai bagian dari wacana. Pendekatan kognitif digunakan untuk mengurai cara berfikir dari penutur melalui ungkapan metafora yang digunakan (Charteris-Black, 2004, 2011; Kövecses, 2010; Lakoff \& Johnson, 1980). Pendekatan ini juga dapat digunakan untuk mengungkap fungsi kognitif dari ungkapan metaforis. Sementara itu, pendekatan pragmatik digunakan untuk mengungkap fungsi pragmatik ungkapan metaforis yang muncul dalam debat pemilihan Gubernur DKI Jakarta tahun 2017.

Data dalam penelitian ini adalah kata, frasa, atau kalimat yang mengandung ungkapan metaforis yang muncul pada Pemilihan Gubernur Jakarta 2017. Data dalam penelitian ini diambil dari Youtube yang memuat perdebatan kandidat gubernur dan kandidat wakil gubernur. Selanjutnya, data hanya diambil dari kandidat Gubernur Anies Baswedan dengan wakilnya Sandiaga Uno dan kandidat Basuki Tjahja Kumala dengan wakilnya Djarot Saiful Hidayat. Metode pengumpulan data menggunakan metode simak dengan teknik baca catat dengan peneliti sendiri sebagai instrumennya (human instrument) melalui beberapa indikator ekspresi linguistik dikatakan metafor dan juga menggunakan sinyal metafora (Charteris-Black, 2004, 2011, Goatly, 1997, 2007; Lakoff \& Johnson, 1980; Newmark, 1988). Adapun prosedur pengumpulan data meliputi: 1) mengamati dan merekam setiap perkataan yang muncul pada debat; 2) membuat transkripsi dari hasil debat; dan 3) membaca hasil transkripsi dan memilih data-data yang mengandung ungkapan metaforis.

Data dianalisis dengan menggunakan metode padan referensial (Sudaryanto, 2015) dan inferensi abduktif (Krippendorff, 2004). Metode padan referensial adalah sub-metode yang menggunakan referensi sebagai perangkat dalam menganalisis data. Sudaryanto (2015: 15) membagi metode padan menjadi lima kategori berdasarkan perangkat penentu, yakni referen bahasa, organ bicara, bahasa lainnya, ortografi, dan lawan bicara. Metode padan referensial digunakan untuk menunjukkan dan membandingkan makna referensial yang terkandung dalam ranah sumber dan ranah sasaran untuk menemukan metafora konseptual dari ungkapan metaforis. Metode ini juga digunakan untuk mengungkap fungsi kognitif dari metafora. Metode inferensi abduktif digunakan untuk menganalisis fungsi metafora, baik mengungkap fungsi pragmatik dari ungkapan metaforis. 


\section{PEMBAHASAN}

Sebagian besar ungkapan metaforis yang ditemukan dalam penelitian ini secara kognitif memiliki fungsi ontologikal dan fungsi struktural. Adapun fungsi orientasional lebih jarang ditemukan dalam debat pemilihan Gubernur DKI Jakarta tahun 2017. Fungsi ontologikal menggambarkan seseorang sebagai benda mati, karakter manusia dengan menggunakan simbol, dan objek yang tak hidup seolah-olah hidup dan bertindak ataupun memiliki sifat seperti manusia. Fungsi struktural menggambarkan konsep abstrak dengan pengalaman manusia terhadap sesuatu, menggambarkan konsep abstrak dengan objek yang lebih konkret, dan menggambarkan karakter manusia dengan menggunakan karakter dari objek tak hidup. Fungsi orientasional metafora yang mengatur seluruh sistem konsep dengan hubungan spasial naikturun. Secara pragmatik ungkapan metaforis pada debat pemilihan Gubernur Jakarta 2017 ini memiliki fungsi legitimasi, delegitimasi, melegitimasi sekaligus mendelegitimasi, mengklarifikasi, menyampaikan penolakan, memberikan pengharapan, menarik perhatian, menjelaskan kasus (isu), memberikan contoh, menunjukkan ketidakadilan, merestrukturisasi frame, memberikan solusi, mengkritik, menunjukkan kepedulian, mengundang berfikir, dan menjelaskan masalah.

\section{Fungsi Kognitif Metafora}

Metafora pada pemilihan Gubernur Jakarta tahun 2017 secara kognitif memiliki beberapa fungsi yang bisa diklasifikasi kepada tiga fungsi ungkapan metafora, yakni ontologis, struktural, dan orientasional. Dalam fungsi ontologis, metafora menggambarkan seseorang seperti layaknya benda takhidup ini telah dijelaskan oleh Charteris-Black (2004: 21) sebagai depersonifikasi yang memunculkan ketegangan semantis. Hal ini terjadi karena adanya penempatan figural yang tidak tepat (Halley, 1980: 143) di mana manusia digambarkan seperti objek takhidup (lihat data 1)

\section{Data 1}

Tapi pemimpin yang mempersatukan itu enggak selalu mudah, apalagi jadi jembatan. Kenapa? Jembatan itu tempat orang yang diinjak-injak. Tapi kalau enggak ada jembatan itu gak bakal ketemu.

Data 1 menunjukkan adanya penggunaan kata jembatan yang mengkonsepsualisasikan seorang pemimpin sebagai jembatan dengan metafora konseptual PEMIMPIN ADALAH JEMBATAN aktif dalam sistem kognisi penutur. Pemimpin yang adalah seorang manusia digambarkan seperti jembatan yang menghubungi tiap-tiap kelas sosial yang ada di Jakarta, yang menurut penutur telah terpecah-belah.

Fungsi ontologis dari metafora yang ditemukan dari penelitian ini juga menggambarkan karakter manusia dengan simbol tertentu (lihat data 2).

\section{Data 2}

Dan kita perhatikan dalam memimpin, membawa hati.

Ini adalah manusia yang punya hak hidup yang sama di Jakarta. Karena itu kenapa kami ingin hadir memimpinnya dengan hati

Pada data 2 "hati" yang merupakan organ terpenting yang membuat manusia tetap hidup disimbolkan sebagai lambang kebaikan, kelembutan, dan kasih sayang. Jadi, seorang pemimpin yang baik harus membawa hati dalam memimpin. Hati di sana mengacu pada sifat manusia yakni baik, lembut, dan memiliki kasih serta sayang sehingga dapat diketahui adanya metafora konseptual KEBAIKAN ADALAH HATI yang muncul dalam piranti kognisi penutur.

Fungsi ontologis metafora yang terakhir yang ditemukan dari penelitian ini adalah menggambarkan objek yang takhidup seolah-olah hidup dan bertindak serta memiliki sifat seperti manusia (lihat data 3) 


\section{Data 3}

Kami akan hadirkan kota yang maju, bahagia, aman, damai, dan bebas dari segala macam kriminalitas.

Siapa bilang Jakarta tidak adil? Siapa bilang Jakarta tidak adil?

Pada data 3 Jakarta sebagai kota digambarkan seolah-olah hidup dan memiliki sifat-sifat seperti manusia, yakni maju, bahagia, dan adil. Penempatan sifat manusia pada benda mati ini menghasilkan ketegangan semantis dengan personifikasi (Charteris-Black, 2004: 21) yang mana menurut Lakoff dan Johnson (1980: 33) adalah fungsi ontologis paling jelas dari metafora konseptual.

Selain fungsi ontologis, data 3 memiliki fungsi orientasional. Kata maju dalam frasa kota yang maju juga memiliki fungsi orientasional yang secara konseptual—dalam sistem bahasa Indonesia gerakan spasial maju menunjukkan keterunggulan dari sesuatu. Jadi, metafora konseptual yang melandasi tuturan metaforis itu adalah MAJU ADALAH KETERUNGGULAN; ketika penutur mengatakan kota yang maju dikarenakan secara konseptual mosi maju bermakna unggul.

Fungsi kognitif lainnya dari metafora yang ditemukan pada debat pemilihan Gubernur Jakarta tahun 2017 adalah fungsi struktural. Fungsi struktural yang ditemukan pada penelitian ini menggambarkan konsep abstrak dengan pengalaman manusia terhadap sesuatu (lihat data 4), menggambarkan konsep abstrak dengan objek yang lebih konkret (lihat data 1), dan menggambarkan karakter manusia dengan menggunakan karakter dari objek tak hidup (lihat data 5).

\section{Data 4}

Jadi kami tidak setuju melakukan bantuan langsung tunai. Karena itu tidak mendidik. Kami seperti orang tua, yang mendidik anak yang rajin harus kerja, yang tidak rajin tidak boleh dapet.

Data 4 menunjukkan fungsi struktural dari ungkapan metaforis yang mengonsepsualisasikan sesuatu yang abstrak seperti konsep kepemimpinan seperti halnya pengalaman manusia dalam membesarkan anak. Pada data 4 ada leksikon mendidik yang secara terus-menerus digunakan oleh penutur sebagai leksikon yang sering digunakan oleh orang tua dan guru. Data 4 juga memperlihatkan adanya kata kerja penghubung (seperti) yang merupakan salah satu indikator ungkapan metaforis. Pada data ini memimpin dikonsepsualisasikan seperti membesarkan anak sehingga dapat dipahami adanya metafora konseptual PEMIMPIN ADALAH ORANG TUA dan ANAK ADALAH RAKYATNYA yang hadir dalam sistem kognisi yang dimiliki penutur.

Selain memiliki fungsi ontologis, data 1 juga memiliki fungsi lain yakni fungsi struktural di mana "kepemimpinan" yang merupakan suatu konsep yang abstrak dikonseptualisasikan dengan menggunakan benda yang lebih konkret yakni "jembatan". Dalam metafora konseptual ini penutur menjelaskan seorang pemimpin yang baik harus punya sifat seperti jembatan yang menghubungkan dua tempat yang terpisah. Dari ungkapan metaforis ini dapat diketahui adanya metafora konseptual PEMIMPIN ADALAH JEMBATAN dan KEPEMIMPINAN SEPERTI JEMBATAN yang dimiliki penutur dalam sistem kognisinya.

Data 5

Supaya kalau kami dilanjutkan lagi bukan hanya visi-misi program tercapai tapi Ahok-nya sudah menjadi iCore 7, i7, bukan Pentium lagi kalau komputer

Pada data 5 pemimpin menggunakan ungkapan metaforis icore 7 dan pentium yang menggambarkan sifatnya sebagai manusia yang dapat ditingkatkan menjadi lebih baik seperti halnya komputer yang dulunya adalah pentium kini menjadi icore7. Ungkapan metaforis ini memperlihatkan adanya metafora konseptual MANUSIA ADALAH KOMPUTER dalam sistem kognisi penutur, yang menggambarkan dirinya sendiri sebagai manusia dapat 
ditingkatkan kualitasnya menjadi lebih baik dengan menggunakan ranah sasaran yakni sifatsifat dari benda tak hidup (komputer).

Fungsi kognitif metafora yang terakhir adalah fungsi orientasional yang pada debat pemilihan Gubernur Jakarta 2017 mengatur seluruh sistem konsep dengan hubungan spasial naik-turun secara koheren memperlihat pola pikir dari penutur atas isu tertentu (lihat data 6).

Data 6

Kami bukan memerangi kemiskinan. Pendiri republik ini tidak pernah mengatakan memerangi kemiskinan.

Mereka mengatakan memajukan kesejahteraan umum. Mereka mengatakan mencerdaskan kehidupan bangsa.

Mereka tidak mengatakan memerangi kebodohan.

Data 6 menunjukkan adanya ungkapan metaforis "memerangi kemiskinan", "memajukan kesejahteraan umum", "mencerdaskan kehidupan bangsa", dan "memerangi kebodohan", memiliki fungsi struktural dan fungsi orientasional. Fungsi struktural menggambarkan kemiskinan dan kebodohan yang dikonsepsualisasikan sebagai musuh dengan menggunakan metafora perang. Selanjutnya, ada fungsi orientasional yang seperti pada data 3 mosi maju secara konseptual merujuk pada keterunggulan. Jadi, ketika penutur mengatakan memajukan kesejahteraan umum kata memajukan merujuk pada meningkatnya kesejehateraan umum. Dengan demikian, gerakan spasial maju dalam sistem Bahasa Indonesia selain menunjukkan keterunggulan dari sesuatu juga dapat dimaknai sebagai meningkatkan sesuatu.

\section{Fungsi Pragmatik Metafora}

Dalam pemilihan Gubernur 2017 metafora memiliki berbagai fungsi pragmatik yang semuanya memiliki tujuan untuk memengaruhi penilaian dari pendengar, yang pada konteks ini adalah calon pemilih. Hal itu dapat dilihat dari fungsi metafora dalam melegitimasi apa yang dikatakan penutur (lihat data 7).

Data 7

Gubernur baru justru akan mengantarkan Jakarta pada kepemerintahan yang lebih efektif, kepemerintahan yang merangkul semuanya, yang membuat semua merasa di rumahnya.

Kata kerja mengantarkan ketika diikuti dengan nomina 'Jakarta' menghasilkan ketegangan semantis karena 'Jakarta' merupakan sebuah kota yang tidak mungkin diantarkan, seolah-olah 'Jakarta' adalah barang yang dikirim oleh porter. Ungkapan ini dikenali sebagai metafora karena merupakan representasi linguistik yang mencolok yang memiliki tujuan memengaruhi penilaian dan pendapat dari pendengarnya (Charteris-Black, 2004: 21) Penutur di sini menggunakan ungkapan metaforis untuk melegitimasi dirinya sebagai calon pemimipin baru 'Jakarta' yang akan membawa perubahan ke arah 'Jakarta' yang lebih baik.

Selanjutnya, ada fungsi metafora yang mendelegitimasi lawan politik dari penutur. Seperti yang diungkapkan Lakoff dan Johnson (1980: 4), debat pada kebanyakan budaya dikonsepsualisasikan sebagai perang yang memunculkan adanya pihak yang menang dan yang kalah. Jadi ungkapan metafora juga digunakan untuk mendelegitimasi lawan politik dengan menunjukkan kelemahan dari lawan politiknya yang dianggap tidak adil (lihat data 8).

\section{Data 8}

$P R$ keadilan di Jakarta masih terlalu banyak. Datanglah ke kampung-kampung di Krukut, yang cuma 4 km dari Balai Kota. Lihatlah kenyataan di sana, bapak akan merasakan ketimpangan yang luar biasa.

Pada data 8 dapat dilihat ungkapan metaforis "PR keadilan" di mana keadilan dikonsepsualisasikan sebagai pekerjaan rumah, sebagai tugas yang diberikan guru kepada siswanya. Metafora ini digunakan penutur untuk menggambarkan bahwa masih terjadi ketimpangan yang belum berhasil diselesaikan oleh lawan politiknya. Data 8 selain memiliki fungsi untuk mendelegitimasi lawan politik juga memiliki fungsi untuk memperlihatkan ketidakadilan dan menunjukkan kepedulian. 
Selanjutnya, ada fungsi pragmatik metafora dalam melegitimasi penutur sekaligus mendelegitimasi lawan politiknya (lihat data 1). Kata "jembatan" secara metaforis mengacu pada pemimpin yang baik yang dapat menyatukan berbagai kelompok sosial yang berbeda seperti mereka yang bekerja dengan mereka yang tidak bekerja, mereka yang sekolah dengan mereka yang tidak sekolah, dan mereka yang kaya dengan mereka yang miskin. Penutur mengatakan menjadi jembatan itu tidak mudah karena tempat orang menginjak-injakan kakinya. Tetapi jika tidak ada jembatan, orang tidak akan bersatu. Di sini, penutur secara kognitif mendefinisikan pemimpin yang baik sebagai jembatan yang dapat menghubungkan kepingan-kepingan, penghalang, yang merujuk pada kelompok sosial yang terpecah-belah. Secara pragmatis, metafora ini memiliki fungsi untuk melegitimasi penutur dan melegitimasi lawan politiknya. Metafora ini mendelegitimasi lawan pembicara dengan tindakan menyalahkan (Hellín-García, 2013: 304). Penutur, sebelum menggunakan metafora "jembatan", menjelaskan bahwa kebijakan lawannya dan gaya bicaranya berkontribusi untuk membuat perpecahan antara kelompok sosial, yang mana berfungsi untuk mendelegitimasi lawan politiknya. Kemudian, dia mengatakan bahwa dia dan rekannya akan menjadi jembatan komunikasi antara kelompok-kelompok sosial yang terpecah-belah untuk melegitimasi dirinya untuk menunjukkan bahwa dia adalah pemimpin yang lebih dapat diandalkan daripada lawannya (legitimasi).

Selanjutnya, ada fungsi pragmatik metafora untuk mengklarifikasi sekaligus dan menyampaikan penolakan (lihat data 3). Penutur mempersonifikasikan 'Jakarta' sebagai manusia yang memiliki sifat adil dengan bertanya "siapa bilang Jakarta tidak adil?". Pertanyaan ini adalah pertanyaan retoris yang mana tujuan bukan untuk bertanya, tetapi untuk menegaskan dan menyampaikan penolakan atas pernyataan lawan politiknya yang menyatakan bahwa 'Jakarta' belum adil. Hal ini dapat terlihat dengan penggunaan repetisi yang dilanjutkan dengan mengklarifikasi bahwa 'Jakarta' telah adil dengan menjelaskan bahwa orang miskin itu tidak bayar PBB.

Selanjutnya ada fungsi pragmatik yang bertujuan memberikan harapan (lihat data 3 ) di mana kota Jakarta dipersonifikasikan seperti manusia yang bahagia. Metafora ini memiliki fungsi pragmatik memberikan harapan kepada rakyat Jakarta, bahwa jika penutur menang, dia dan rekannya akan mampu membawa Jakarta ke arah yang lebih baik, yakni kota yang maju dan bahagia.

Metafora pada penelitian ini juga memiliki fungsi untuk menarik perhatian dan merestrukturisasi frame (lihat data 9).

\section{Data 9}

Kami adalah pelayan warga Jakarta. Dengan tulus kerja kami untuk Jakarta.

Ketuk pintu, layani dengan hati. Dengan hati betul-betul.

Oleh sebab itu kami mohon dengan sangat, kami tidak bisa memuaskan semua orang.

Sehingga apapun pilihan bapak ibu sekalian kita tetap sebagai satu saudara karena kita adalah pelayan warga, kepala daerah yang melayani warga dengan sepenuh hati.

Pada data 9 dapat dilihat bahwa ada kata "pelayan", "layani", dan "memuaskan" yang terus digunakan oleh penutur yang merujuk pada konsep kepemimpinan yang melayani. Dalam dunia pelayanan, orang memberi perintah maka pelayan akan bekerja untuk mendapat bayaran. Hal ini bertentangan dengan frame seorang pemimpin-dalam konteks ini Gubernur, yang merupakan perwakilan "pemerintah" yang dalam bahasa dan budaya Indonesia merupakan turunan dari kata "perintah". Artinya orang yang memberi perintah dan rakyat harus mengikuti. Metafora ini secara pragmatis memiliki fungsi untuk menarik perhatian dengan memberikan pandangan bahwa meskipun sebagai pemimpin, mereka bekerja untuk melayani masyarakat Jakarta. Selanjutnya, metafora ini merestrukturisasi frame dari pemimpin dengan menggunakan konsep pelayan dalam memerintah. Dengan metafora ini, mereka ingin menunjukkan kepada 
orang-orang bahwa mereka bukan pemimpin yang hanya tahunya memberikan perintah, tetapi juga pemimpin yang mampu melayani rakyatnya.

Selanjutnya, ada fungsi pragmatik metafora dalam menjelaskan kasus (lihat data 10) dan memberikan contoh (lihat data 11) yang merupakan konsep kepemimpinan.

Data 10

Sama kayak tadi dia bilang tidak adil, justru kami mengadministrasi keadilan sosial. Misalnya di Krukut, kenapa kita pindahkan dia ke rumah yang lebih baik. Karena dia tidak mampu beli rumah, makanya kita sediakan rumah susun.

Pada data 10 ada ungkapan metaforis "mengadministrasi keadilan sosial" yang digunakan untuk menjelaskan kasus penggusuran yang dilakukan oleh pemerintah yang dipimpin oleh penutur. Penutur menjelaskan bahwa yang dia lakukan justru merupakan keadilan karena dia memindahkan para manusia yang tinggal di bantaran sungai, yang tinggal di rumah yang tidak layak, dan yang tidak mampu membeli, maka disediakanlah rumah susun. Metafora ini menunjukkan keadilan seolah-olah dan manusia adalah benda fisik yang dapat dikelola dengan memindah-mindahkan tempat tinggalnya.

Data 11

Kalau kita ngedepankan to lead by example. Leading adalah memberikan contoh. Memimpin dengan memberikan contoh.

Data 11 menunjukkan adanya metafora dari konsep kepemimpinan yang menggunakan konsep dari panutan. Seorang panutan adalah seseorang yang memberikan contoh. Jadi, pemimpin pada ungkapan metaforis ini adalah pemimpin yang memberi contoh. Selanjutnya, penuturnya juga mengatakan seorang pemimpin harus dapat menggerakan masyarakat, memobilisasi warga yang merupakan suatu konsep kepemimpinan yang dianut penutur. Selain itu, ungkapan metaforis ini bertujuan untuk memberikan solusi tentang kemacetan di Jakarta yang menjadi isu pembahasan dalam debat. Penutur menyampaikan pemimpin harus memberi contoh dan menjadi panutan untuk ikut naik kendaraan umum sehingga kemacetan dapat dikurangi. Fungsi lain dari metafora ini adalah merestrukturisasi frame dari kepemimpinan yang dianut lawan politiknya sebagai kepemimpinan yang melayani. Metafora ini berkontribusi dalam perang wacana tentang kepemimpinan yang mewarnai debat pemilihan Gubernur Jakarta 2017.

Secara umum ungkapan metaforis yang muncul dalam debat pemilihan Gubernur Jakarta tahun 2017 menggambarkan adanya perbedaan cara pandang setiap kandidat terhadap isu tertentu. Berbagai isu diperdebatkan seperti isu tentang keadilan, kemiskinan, dan kepemimpinan di mana setiap kandidat memiliki pemahaman yang berbeda yang berkontribusi pada bagaimana mereka mengkonstruksi wacana. Hal ini disebabkan oleh cara pandang dan pengalaman yang berbeda dari setiap orang sehingga ekspresi metafora yang digunakan juga dapat berbeda meskipun mereka memperdebatkan satu konsep yang sama. Ekspresi metafora yang berbeda ini dapat menunjukkan apa yang ada di pikiran penutur tentang isu tertentu.

Dari hasil pembahasan dapat ditemukan bahwa fungsi kognitif metafora membantu manusia memahami suatu fenomena baru atau abstrak konsep dengan pengalaman yang lebih spesifik atau akrab. Latar belakang penutur secara kognitif (tanpa sadar) berkontribusi memengaruhi pilihan ranah sumber yang digunakan untuk menjelaskan ranah sasaran. Hal itu disa dilihat dari data 8 di mana muncul metafora "PR keadilan" yang digunakan karena penutur adalah seorang pendidik - atau bisa dikata mantan pendidik. Secara pragmatik metafora pada debat pemilihan Gubernur memiliki fungsi yang secara tidak langsung bertujuan untuk memengaruhi pendengar dengan menggunakan ranah sasaran dari benda konkret, atau pengalaman yang akrab dan dapat dimengerti oleh berbagai kalangan masyarakat. Selain itu, dengan menganalisis metafora secara kognitif dapat membantu untuk mengungkap fungsi pragmatik dari ekpresi metafora. 


\section{PENUTUP}

Ungkapan metaforis dalam debat pemilihan Gubernur Jakarta tahun 2017 mayoritas memiliki fungsi struktural dan ontologikal. Fungsi struktural menggambarkan konsep abstrak dengan pengalaman manusia terhadap sesuatu, menggambarkan konsep abstrak dengan objek yang lebih konkret, dan menggambarkan karakter manusia dengan menggunakan karakter dari objek tak hidup. Fungsi ontologikal menggambarkan seseorang sebagai benda mati, karakter manusia dengan menggunakan simbol, dan objek yang takhidup seolah-olah hidup dan bertindak ataupun memiliki sifat seperti manusia. Fungsi orientasional lebih jarang ditemukan. Ungkapan metaforis pada debat pemilihan Gubernur DKI Jakarta bertujuan untuk mendapatkan suara pemilih, yakni masyarakat Jakarta, maka segala isu dimunculkan dengan menggunakan metafora yang secara tidak langsung memiliki fungsi pragmatik untuk melegitimasi, mendelegitimasi, melegitimasi sekaligus mendelegitimasi, mengklarifikasi, menyampaikan penolakan, memberikan pengharapan, menarik perhatian, menjelaskan kasus (isu), memberikan contoh, menunjukkan ketidakadilan, merestrukturisasi frame, memberikan solusi, mengkritik, menunjukkan kepedulian, mengundang berfikir, dan menjelaskan masalah. Secara umum metafora yang muncul pada debat pemilihan Gubernur DKI Jakarta memilki fungsi untuk membantu menyederhanakan isu-isu politik untuk memberikan kemudahan kepada audiens dalam memahami isu yang kompleks dan rumit.

\section{DAFTAR PUSTAKA}

Charteris-Black, J. (2004). Corpus Approaches to Critical Metaphor Analysis. New York: Palgrave Macmillan. https://doi.org/10.1057/9780230000612

Charteris-Black, J. (2011). Politician and Rhetoric: The Persuasive Power of Metaphor (2 ${ }^{\text {nd }}$ Edition). Basingstoke: Palgrave Macmillan. https://doi.org/10.1057/-9780230319899

Croft, W., \& Cruse, D. A. (2004). Cognitive Linguistics. Cambridge: Cambridge University Press. https://doi.org/10.1017/CBO9780511803864

Goatly, A. (1997). The Language of Metaphors. New York: Routledge. https://doi.org/10.4324/9780203210000

Goatly, A. (2007). Washing the Brain - Metaphor and Hidden Ideology. John Benjamin Publishing Company. https://doi.org/10.1075/dapsac.23

Halley, M. C. (1980). Concrete Abstraction: The Linguistic Universe of Metaphors. In M. K. L. Ching, M. C. Halley, \& F. R. Lonsford (Eds.), Linguistic Perspective on Literature. London: Routledge \& Kegan Paul Ltd.

Hartanto, W. (2018). Metafora Kognitif Tuturan Penceramah dalam Pengajian di Wilayah Surakarta. Kandai, 14(2), 181-196. https://doi.org/10.26499/jk.v14i2.643

Hellín-García, M. J. (2013). Legitimization and Delegitimization Strategies on Terrorism : A Corpus-Based Analysis of Building. Pragmatics, 330(2), 301-330. https://doi.org/10.1075/prag.23.2.05hel

Kövecses, Z. (2010). Metaphor (Second Editiin). New York: Oxford University Press.

Krippendorff, K. (2004). Content Analysis: An Introduction to Its Methodology. London: Sage Publications Inc.

Lakoff, G., \& Johnson, M. (1980). Metaphors We Live By-University Of Chicago Press (1980).pdf (First). Chicago: University Of Chicago Press.

Newmark, P. (1988). A Textbook of Translation. Englewood Cliffs: Prentice Hall International. Nirmala, D. (2011). Metaphors: Universal, Spesific, and Public. Bahasa dan Seni, 39(2), 250265.

Nirmala, D. (2012). Fungsi Pragmatik Ungkapan Metafora dalam Wacana Surat Pembaca Berbahasa Indonesia. Litera, 11(1), 34-46. https://doi.org/10.21831/ltr.v11i1.1141 
Ranabumi, R. (2018). Metafora Pada Lagu Nyidham Sari dan Yen Ing Tawang ono Lintang. Ranah, 7(2), 247-262. https://doi.org/10.26499/rnh.v7i2.659

Sudaryanto. (2015). Metode dan Aneka Teknik Analisis Data. Yogyakarta: Sanata Dharma University Press.

Sukarno. (2017). Makna dan Fungsi Ungkapan Metaforis dalam Wacana Hukum pada SUrat Kabar Harian Jawa POs. Jurnal Pendidikan Bahasa Dan Sastra, 17(1), 15-28. https://doi.org/10.17509/bs_jpbsp.v17i1.6954

Supriyadi. (2013). Ungkapan-Ungkapan Metaforis dalam Puisi-puisi Karya Agus R. Sardjono. Litera, 12(2), 1-22. https://doi.org/10.21831/ltr.v12i02.1591

Ulya, C., Eko, N., \& Mujiyanto, Y. (2016). Metafora dalam puisi antikorupsi karya penyair indonesia. AVATISME , 19(2), 206-219. https://doi.org/10.24257/atavisme.v19i2.246.206$\underline{219}$ 